\title{
Introduction: The regulation of franchising in the new global economy
}

'In the time of the legendary King Arthur, the quest for the Holy Grail was the highest spiritual pursuit for a knight. Today, franchise reformers search for their own Holy Grail - a convenient formula to deliver balance and equity to the franchise relationship which is commonly characterised by both a power and an information imbalance.' 1

The concept of business-format franchising originated in the United States of America in the late 1950s and saw rapid expansion there in the 1960s and 1970s. As the phenomenon of business-format franchising has taken hold in many countries around the globe regulation of the sector internationally has increased with a trend toward regulation that has been particularly notable in the years since 1990. The franchise sector was first regulated in the 1970s in the US and Canada. In 1980 only the US and Canada had franchise-specific legislation. By 1990 France and Mexico had joined them. By the year 2000 about thirteen jurisdictions had implemented franchisespecific legislation including Australia, Brazil, the People's Republic of China, Taiwan, Indonesia, Malaysia, Romania, and Spain.

Since the year 2000 another 16 countries have followed suit. Today about 30 countries, or about one-third of the countries where franchised business operates, have enacted regulation directed specifically towards franchising or with the specific intention to capture franchising. These countries include Canada (four of ten provinces: Alberta; Ontario; New Brunswick; Prince Edward Island), the US, Barbados, Brazil, Mexico, Albania, Belarus, Belgium, Estonia, France, Italy, Lithuania, Moldova, Romania, Russia, Spain, Sweden, Ukraine, People's Republic of China, Indonesia, Japan, Kazakhstan, South Korea, Kyrgyzstan, Macau, Malaysia, Vietnam, Taiwan, and Australia. The countries included in this list where regulation is not strictly or solely franchise-specific, but where the intention has been to capture franchising include Albania, Belgium,

1 Andrew Terry, 'Franchising and the Quest for the Holy Grail: Good Faith or Good Intentions?', 23rd Annual International Society of Franchising Conference, San Diego, CA, February 2009. 
Belarus, Estonia, France, Georgia, Kyrgyzstan, Lithuania, the People's Republic of China, Taiwan, Russia and Ukraine. ${ }^{2}$

The reasons for the increase in regulation of the sector include an increase in international franchise activity and the recognition of franchising as a unique business model that demands a particularized regulatory scheme. Currently the forms the laws take are not uniform, despite the promulgation in 2002 of the UNIDROIT Model Franchise Disclosure Law. Many countries have responded to problems in the sector with regulatory measures, but some countries, such as England, Germany and the Netherlands, seem to do well with no sector-specific legislation at all. Other countries, such as Sweden, have enacted only minimal regulation. Variation in legislation is to be expected because regulation in each jurisdiction must respond to its own particular circumstances and requirements and because regulation as governance reflects the global diversity of conceptions about the kind of people and societies we are and aspire to be.

At the same time there is also a compelling argument for harmony in regulation internationally to the extent that it is feasible and practicable. Consistency in private law provides a legal framework of private rights as the foundation for social interaction. An international legal regime facilitates transactions, enhances credit facilities and reduces borrowing costs. ${ }^{3}$ In order to maximize the benefit of such harmonization, regulation should be understood and applied as consistently as is practicable.

This book is an undertaking that has been motivated principally by two factors. The first is a discernible trend globally to regulate the franchise sector. The second is the lack of consensus on what that regulation should look like. 'The increasing influence of franchising has . . been accompanied by an increasingly vigorous debate as to the regulatory environment for franchising. ${ }^{4}$ It is hoped that the global survey and analysis of this aspect of the regulation of the franchise sector provided here will lead to better understanding and harmonization of that regulation.

The book is organized in three parts. The first provides introductory material, an overview of the nature of regulatory theory as well as an overview of the nature of the franchise sector. The second part comprises a survey of the regulation of the sector. The survey of regulatory measures

2 Venezuela is not included as the legislation directed toward franchising in that country is only for the purposes of exempting franchising from certain competition law requirements.

3 See http://www.uniformlaw.org/important.php at 14 December 2009.

4 Andrew Terry, 'A Census of International Franchise Regulation', 21st Annual International Society of Franchising Conference, Las Vegas, Nevada, 24-25 February 2007, 3. 
provides an indication of where we are in the progress toward the optimum regulatory program for the sector globally, and an orientation for future plans for regulation. The third part of the book offers a comparative analysis of the current approaches to regulating in light of the concepts for optimum regulation suggested by current regulatory theory.

This book challenges some of the commonly-held myths about both regulation and franchising; first, with the proposition that franchising in fact does have risks and dangers for its participants, and second, with the proposition that appropriate regulation can help to minimize the damaging effects of these risks and so benefit the health and competitiveness of the sector overall. Rather than reinforcing the belief that franchising is low risk, this book argues that franchising must be understood in terms of its risks. This is the logical starting point for regulatory intervention. Rather than reinforcing the belief that regulation is something to be avoided, this book argues that there are multiple levels at which regulation operates, and that it can and should be properly calibrated in order to provide sophisticated, appropriate regulation at each 'layer' of governance.

\section{RECONCEIVING REGULATION}

There is a commonly-held belief that regulation is bad for business, and that the heavy hand of government intervention in peoples' private affairs should be avoided at all costs. Such a belief may often be justified; but as often it is not. It is said that judgments are alienated expressions of needs, and certainly there are needs that are not being met by regulation. ${ }^{5}$ The widespread mistrust of regulation is the result of years of high costs and intangible benefits of regulation that have eroded public confidence in the efficacy of regulation. In 2001 the US Office of Management and Budget estimated the cost of federal regulations at $\$ 380$ billion per annum, or about ten percent of the US gross domestic product (GDP) (more than half the output of the US manufacturing sector). ${ }^{6}$ Despite the high cost that it is asked to pay for regulation, however, the public does not see its worth. A 2004 report showed that 53 percent of Americans agreed that 'Government regulation of business usually does more harm than good. ${ }^{7}$ Clearly, needs are not being met.

It is true that inefficient regulation can erode confidence, impede growth,

5 M. Rosenberg, Nonviolent Communication: A Language of Life (2003) 52.

6 James L. Gattuso, 'Reforming Regulation to Keep America's Small Businesses Competitive' (2004) The Heritage Foundation <http://www.heritage. org/Research/Regulation/tst052104a.cfm\#_ftn2\#_ftn2> at 14 December 2009.

$7<$ http://people-press.org/report/?pageid=756> at 23 December 2009. 
and retard needed change. It may limit the expansion of consumer choice, reduce entrepreneurial initiative, and often advantages some unfairly at the expense of others, small business for example. ${ }^{8}$ Because many regulatory costs fall disproportionately on small business; if regulation is ineffective, small business feels it first. ${ }^{9}$ There are, however, significant benefits to efficient and effective regulation, though they are often harder to quantify than the costs. Appropriate regulation can enhance economic growth and competitiveness, as regulatory regimes support the growth of local economies and global economic development. ${ }^{10}$

As the current global financial crisis continues to unfold, there can be no doubt that there are consequences to regulatory inaction. In place of neo-conservative principles of de-regulation and unbounded faith in markets, there is a renewed appreciation of the potential benefit of effective regulation to enhance competitiveness by ensuring effective and fair commerce. There is in the public discourse an 'increasing sense of anxiety surrounding deregulation' because market processes cannot be relied upon to adequately serve the public interest. ${ }^{11}$

Properly targeted and implemented regulatory measures can reduce costs of unfair practices and failed business, reinvigorate consumer confidence and stimulate investment. An effective regulatory scheme can attract foreign investment and facilitate local expansion overseas. Some experts advise businesses to seek out areas with progressive regulation in terms of concern with social problems, and to set internal goals that meet or exceed regulatory standards because this ultimately leads to advantage as

8 Sveinbjörn Blöndal and Dirk Pilät, 'The Economic Benefits of Regulatory Reform' (1997) 1 OECD Economic Studies No. 28 [29] <http://www.oecd.org/ dataoecd/22/21/2733617.pdf $>$ at 14 December 2009.

9 A Crain and Hopkins study found that firms employing fewer than 20 people faced regulatory costs of almost $\$ 7,000$ per employee, compared to an average of $\$ 4,700$ for all firms, not including indirect burdens and secondary costs. See W. Mark Crain and Thomas D. Hopkins, 'The Impact of Regulatory Costs on Small Firms: A Report for the Office of Advocacy, US Small Business Administration,' RFP No. SBAHW-00-R-0027.

10 Sveinbjörn Blöndal and Dirk Pilät, 'The Economic Benefits of Regulatory Reform' (1997) 1 OECD Economic Studies No. 28 [30] <http://www.oecd.org/ dataoecd/22/21/2733617.pdf $>$ at 14 December 2009. On the distinction between the regulation of standards and the regulation of competition, see Michael E. Porter, The Competitive Advantage of Nations (1990). The topic is also discussed in John Braithwaite, 'Responsive Regulation for Australia' in Peter Grabosky and John Braithwaite (eds), Business Regulation and Australia's Future (1993).

11 Karen Gustafson, 'The New Economy and Internet Regulation: Discourses of Inevitability' (Paper presented at the 57th Annual International Communication Association Conference, San Francisco, CA, 24 May 2007). 
other jurisdictions modify their regulations to follow suit. ${ }^{12} \mathrm{~A}$ well-defined legal structure is indispensable for the effective functioning of any business operation and the lack of comprehensive legislation can lead to greater complexity, ambiguities and uncertainty. Commercial interests in any jurisdiction therefore should seek to promote a measured approach toward achieving effective and efficient regulation in order to enhance competitiveness and the effective function of markets and, ultimately, to enhance the quality of life in both economic and social spheres.

Regulation is inevitable. All commerce is underpinned by a legal framework and infrastructure. Not only that, all commerce is regulated privately; specifically at the 'layers' of market and contract the parties use various means to control the nature of their interactions. The question then is not whether to regulate, but how to regulate.

The global financial crisis provided a stark reminder that the economic climate and the regulation of business in economies around the globe can and do impact each other significantly. Regulating business in a post-global-financial-crisis world is likely to involve greater emphasis on the prophylactic benefits of regulation, as a result of a widespread disillusionment with laissez-faire approaches that allow unscrupulous people to profit to the detriment of all. There is less tolerance for 'sharp' business practice and a greater recognition that we all pay for financial opportunism, often on a grand scale, and that we need regulation for the benefits and competitive advantage that good governance can offer.

However, increasing complexity in markets and higher levels of specialization mean it is harder than ever for regulators to comprehend and respond to risks in the marketplace. During the financial instability in the US prior to World War II Franklin D. Roosevelt was able to shut the banks, to take time to analyse and address the particular problems that had caused the most damage to the economy.

Today, it appears to be impossible to unravel the interconnected web of global trade and finance, and the luxury of sufficient time to fully analyse problems and formulate plans seems to be a relic of a bygone era. Further, there seems less consensus than ever on what the role of government can and should be in market intervention:

Welfare economics supports the concept that failure to satisfy the conditions for perfect competition can justify government intervention in markets ... but this market failure approach is open to question ... The difficulty facing regulatory

12 Peter Grabosky and John Braithwaite (eds), Business Regulation and Australia's Future (1993) 88, citing Michael E. Porter, The Competitive Advantage of Nations (1990). 
authorities is how to differentiate between situations requiring intervention and those that do not ... in general, government intervention is not necessarily the only or even the best solution to instances of market failure . . . also, spillover effects of regulatory actions in one jurisdiction can impact on other jurisdictions and necessitate coordination in a globalised economy. ${ }^{13}$

The answers therefore have to be quicker, with greater reliance on insider/ expert knowledge and with awareness of synergies of the ecologies of markets and industries. They must be more self-regulatory, responsive and reflexive, with greater reliance on the expertise and on-the-spot assessments of the participants themselves.

The answers also must be global and broad-based in perspective as the new global economy is more interconnected than ever before. The concept of globalization can mean many things; in this book it is used to refer to, 'a process in which the structures of economic markets, technologies, and communication patterns become progressively more international over time'. ${ }^{14}$ The growth of international trade, the expansion of transnational enterprise, and increased interactions of financial markets are components of this process which has significant implications for national economies and global change. ${ }^{15}$

The Malaysian franchise sector's targeted expansion into Middle Eastern markets illustrates the connections among countries and regions such as Southeast Asia and the Middle East and among industry sectors such as tourism and fast food:

The Malaysians have been particularly successful in the area of introducing new food and fashion brands to the Gulf. Malaysia's current drive, promoting itself as a preferred holiday destination for people from the Gulf, is assisting the drive to export Malaysian brands. Tourists experience the local brands abroad and readily accept them in Saudi when they are introduced. The tourist drive further enhances the concept of brand Malaysia? ${ }^{16}$

13 Boon-Cheye Lee, 'Regulation and the New Economy' (Working Paper 02-18, University of Wollongong, NSW, Australia, 2002) 15-16. Available at $<$ http:// ro.uow.edu.au/cgi/viewcontent.cgi?article $=1063 \&$ context $=$ commwkpapers $>$ at 19 December 2009.

14 OECD, 'Environment and Globalisation: Background Report for Ministers' (Report for meeting of the Environment Policy Committee at Ministerial Level, Environment and Global Competitiveness, 28-29 April 2008) < http://www.oecd. org/dataoecd/3/59/40511624.pdf> at 19 December 2009.

15 Rhys Jenkins, Jonathan Barton, Anthony Bartzokas, Jan Hesselberg and Hege Merete Knutsen, Environmental Regulation in the New Global Economy: The Impact on Industry and Competitiveness (2002).

16 Franchiseek Limited, 'Saudi Arabia Franchise Statistics' (2009) <http:// www.franchiseek.com/Saudi_Arabia/Franchise_Saudi_Arabia_Statistics.htm $>$ at 14 December 2009. 
No single company is driving the expansion of Malaysian franchising in the Gulf region; instead the entire Malaysian franchise sector is the brand in this process of market development and international expansion, facilitated by effective regulation. 'The need for countries to cooperate and coordinate their policies is perhaps the key conclusion. ...'17

Finally, the answers must also be based on durable human values. Current academic literature reflects this; it is about 'humanizing the firm', recognizing the economic value of trust and integrity in commercial environments. What is needed is regulation of commerce both on a human and a municipal scale that comprehends and responds to global conditions. Just as franchising itself combines local 'touch' with worldwide proportions, regulation must comprehend the multiple layers of commercial interaction and respond to them with careful, balanced measures in order to maximize the productivity of commercial enterprise while minimizing its inefficiencies and negative externalities.

\section{THE IMPORTANCE OF FRANCHISING}

In the post-World War II period franchising has proved to be a remarkably successful business model, adaptable to many different industries and commercial applications as well as to the sharing of intellectual property for social welfare initiatives. Though franchising is often identified with the 'small end of town', franchising in fact represents big business and small business alike. Today, franchised businesses operate in about twothirds of the approximately 192 countries in the world and make a major economic contribution. McDonald's Corporation has over 31,000 stores in approximately 120 countries, ${ }^{18}$ and in 2008 reported sales revenue of US\$23.5 billion. ${ }^{19}$ Yum! Brands (owner of the Kentucky Fried Chicken, Pizza Hut, Taco Bell and Long John Silver brands) has 35,345 stores in over 100 countries and in 2008 reported revenue of US $\$ 11.3$ billion. ${ }^{20}$

17 Boon-Cheye Lee, 'Regulation and the New Economy' (Working Paper 02-18, University of Wollongong, NSW, Australia, 2002) 16. Available at $<$ http:// ro.uow.edu.au/cgi/viewcontent.cgi?article $=1063 \&$ context $=$ commwkpapers $>$ at 19 December 2009

18 McDonald's Corporation, 'Frequently Asked Questions' (2009) McDonald's $<$ http://www.aboutmcdonalds.com/mcd/students/faq_for_students.html\#10> at 19 December 2009.

19 <http://finance.econsultant.com/mcdonalds-2008-revenue-profit-2009fortune-500-rank/> at 23 December 2009.

20 <http://www.yum.com> at 23 December 2009. 
Franchising is also a major sector of many national economies, where its efficient operation impacts economic, social and political conditions. While reliable measurements of activity in the franchise sector are notoriously difficult to obtain, reports from many jurisdictions do suggest its importance. In Canada franchising revenues are estimated at $\$ 30$ billion, accounting for approximately 10 percent of GDP. In the US about 40 percent of all US retail sales may be attributed to franchise units, franchising is also estimated to account for approximately 10 percent of GDP. In Peru approximately 70 Peruvian and foreign franchise businesses now operate, generating an estimated 3,250 direct jobs and sales reaching US\$375 million. In Belgium the annual sales turnover through these outlets is about $€ 2.4$ billion, or about 6 percent of retail trade. The total market for franchising in Finland was estimated at $\$ 5.4$ billion. German franchising, with sales at about US\$2 million, accounts for about 1.6 percent of total national GDP. Annual sales through franchise outlets in the Netherlands accounted for approximately $\$ 23$ billion worth of sales in 2004. In India franchising accounts for 3 percent of India's total retail; the market is estimated to be $€ 2$ billion. In Malaysia, by some estimates franchising contributes over 12 percent of the country's GDP. In Japan more than 1,000 franchisors operate over 198,000 outlets and generate an annual turnover of more than US\$142 billion. In Singapore franchising accounts for an estimated A $\$ 80$ billion (12 percent of the GDP). And the list goes on.

Franchising is not only an important part of the global economy currently, but also it is on the increase worldwide. ${ }^{21}$ In Norway there are approximately 250 different franchising systems in operation, an increase of 32 percent since $1998 .^{22}$ Sixty of the 107 franchises currently operating in Romania have been established during the last two years. ${ }^{23}$ In Egypt continued growth is expected at an annual rate of 10 to 20 percent, ${ }^{24}$ while an average annual growth rate of 25 percent is estimated for the region of the Middle East. ${ }^{25}$ In New Zealand the sector is expected to continue to

21 Diez-DeCastro, Navarro-Garcia, Rodriguez-Raz, Rondan-Cataluna, 'Membership in the Franchising System: A Worldwide Analysis' (Speech delivered at the 22nd Annual International Society of Franchising Conference, Saint-Malo, Brittany, France, 20-21 June 2008).

22 Britt Hestenes, 'Franchising in Norway' (2006) United States of America Department of Commerce <http://www.buyusainfo.net/docs/x_3120014.pdf> at 28 December 2008.

23 Roxana Negutu, 'Romania - A New Player On The Market' (30 May 2008) http://www.franchise-update.com/article/573 at 19 December 2009.

$24<$ http://www.nixonpeabody.com/publications_detail3.asp?ID=2795> at 25 December 2009.

25 <http://www.ameinfo.com/156782.html> at 25 December 2009. 
grow at up to 20 percent per annum, while in Australia the sector continues to grow domestically, and about 20 percent of its franchisors are looking at expanding overseas. ${ }^{26}$

The franchise business model is expanding because of its potential as a versatile and dynamic organizational form. It is a model that has been described by law and economics theorists as 'federated', combining largescale economies of big business with the local 'touch' of local enterprise. ${ }^{27}$ The many benefits of franchising include its ability to facilitate the efficient expansion and adoption of good business practices; to rapidly develop intellectual property both domestically and internationally; to promote the growth of small business; and to provide a vehicle for investment as well as for training of fledgling entrepreneurs in both mature and developing economies. Franchising combines the advantages of small- and large-scale enterprise; it is personal and accessible, while at the same time it achieves important economies of scale and international brand recognition.

This book is focused on the regulation of the franchising sector, especially on franchise-specific legislation. Because legislation by governments only comes into play when there are problems that need to be addressed, by its very nature this book is about problems in the franchising sector. This is not meant in any way to detract from the successful organizational form that franchising represents. Franchising continues to grow, continues as a successful business form, and that is exactly why the regulation of this sector is important and should comply with best practice, representing the highest examples of integrity and expertise in regulating.

\section{THE REGULATION OF FRANCHISING IN THE NEW GLOBAL ECONOMY}

The book is arranged in two parts. The first part deals with both regulation and franchising in conceptual and practical terms. Chapter 1 establishes the regulatory context for the survey of the regulation of franchising, which is based on a 'new learning' on regulation, with a focus on three concepts. The first is the importance of self-regulatory tools and strategies. The

26 'An Overview of the Status of Franchising Internationally', http://www. afdb.org/fileadmin/uploads/jai/Course-Materials/04-FRANCHISING-WITHINSME-DEV-STRATEGY/day1/1.3-louw-an-overview-of-the-status-of-franchising -internationally.doc. at 25 December 2009.

27 See, eg, Oliver Williamson, Markets and Hierarchies: Analyses and Antitrust Implications (1975); Oliver Williamson, The Economic Institutions of Capitalism (1985). 
second is that regulation as governance happens at multiple 'layers', all of which must be considered in any regulatory program. The third concept is that regulation should follow a process that encompasses reliable information and the input of all stakeholders through democratic, participative process. These concepts serve as the underlying framework for theoretical approach to regulation in the book.

The first part of the book continues with the thread of the 'new learning' as it outlines in Chapters 2 and 3 the governance of franchising at private 'layers' of market and contract, and its implications with respect to the franchise relationship. The phrase 'the franchise relationship' refers to the relationship between franchisor and a franchisee. Legislation directed towards that interaction is described as 'franchise-specific legislation'. As the Explanatory Report for the UNIDROIT Model Law points out, one of the characteristics of franchising is that a number of areas of law are involved, many of which are already regulated. It is therefore, 'difficult to justify adopting a discipline specifically for franchising in relation to, for example, contract law, choice of law and jurisdiction, or intellectual and industrial property law'. ${ }^{28}$ A comparison of the legislation regarding all these aspects of franchising, though significant, lies outside the scope of this study.

Chapter 2 describes the fundamentals of the interaction between franchisor and franchisee at the level of the market. Some of the problems that arise frequently in the course of the franchise relationship are outlined, with the caveat that this material is presented only to provide an understanding of the issues for the purposes of this book. It is in no way intended as a substitute for participation in regulatory process in any given jurisdiction. The main issues that are raised for this purpose are the importance of uniformity, the corollary of which is franchisor control, and lack of reliable information about the sector and about franchise systems, which leads to asymmetries of information and acts as a substrate for the promulgation of myths.

Chapter 3 proceeds from the premise that best practice in regulatory process requires a comprehensive understanding of the context of regulation. Because the context of regulating franchise relationships is contract, ${ }^{29}$ an accurate understanding of the nature of the contractual agreement is

28 UNIDROIT, 'Model Franchise Disclosure Law: Explanatory Report' (2002) p. 13. <www.unidroit.org/english/modellaws/2002franchise/2002modellawe.pdf $>$ at 19 December 2009.

29 Gillian Hadfield, 'Problematic Relations: Franchising and the Law of Incomplete Contracts' (1990) 42 Stanford Law Review 927, 939: '[T]he heart of franchising's legal structure is still contract'. 
critical to understanding the relationship. Chapter 3 explains the full implications of the fact that franchise agreements 'are long-term, standard-form contracts' ${ }^{30}$ first in theory and second through an examination of contract terms in franchise agreements as they represent the competing interests of franchisors and franchisees.

Though its benefits are well-documented, franchising does have risks for both parties, but the risks are easier for franchisors to address through careful drafting of contract terms than they are for franchisees. In fact, franchisors often shift their business and financial risks to franchisees. The contextual framework for understanding the regulation of franchising provided in the first part of the book suggests that franchising carries risks that are reinforced by the parties' private self-regulation through their market and contractual interactions. Therefore, the market inefficiencies and social welfare problems that may result do warrant public intervention.

The second part of the book provides a global survey and analysis of how the sector is currently regulated through statutory regulation, franchise-specific legislation. Chapter 4 outlines the articulated purposes of sector-specific legislation where it is available. It also surveys the scope of the legislation according to the various definitions used for franchising in the legislation.

Chapter 5 provides a general country-by-country overview of legislation globally. For each jurisdiction that regulates the sector some general statistical information about population and economic productivity are included to provide a context for the survey information about the regulatory climate. The survey gives information about disclosure; registration; other pre-sales measures; measures targeted towards performance of the agreement; dispute resolution; good faith where applicable; and in some cases administration and enforcement.

The survey in Chapter 5 of this legislation provides the material for an analysis of trends in the statutory regulation of franchising. Chapter 6 begins the book's analysis and discussion of franchise-specific regulation, identifying the common themes and trends. Chapter 7 summarizes the tools and approaches used in franchise-specific regulation with respect to regulation through disclosure, registration, and other pre-sales measures such as cooling-off and standards and qualifications. Chapter 8 deals with legislation directed toward the conduct of and exit from the franchise

30 Gillian Hadfield, 'Problematic Relations: Franchising and the Law of Incomplete Contracts' (1990) 42 Stanford Law Review 927, 946. Having made this observation, Hadfield focused the balance of her analysis primarily on the incompleteness of the contract rather than the standard form or the combination of the two. 
relationship, in other words performance-oriented legislation, including mandatory content; prescribed procedures for dispute resolution, transfer and termination; and also a requirement of good faith. Chapter 9 concludes with some discussion of directions for the reconception of regulation at all 'layers' of governance.

This book surveys franchise-specific regulation globally; it is not a comprehensive manual or analysis of regulation of the franchising sector in any given jurisdiction. Rather, it surveys legislation from a broad perspective in order to identify patterns and trends and so to serve as a starting point for understanding the regulation of franchising as well as other commercial regulation, taking into account the context of the relationship, the nature of the contract, and the nature of the commercial interaction. Rather than a practice-oriented resource, this book identifies patterns in statutory intervention in the sector and provides a conceptual analysis of the regulation of the franchise sector globally. Such information can lead to better analysis of how such tools work, to what extent they are effective and in what combinations they may best be applied to achieve agreed regulatory objectives.

While it has not been within the scope of this book to survey case law in each jurisdiction, this is an important area for further study as each jurisdiction, region and/or legal tradition will have a history of case law and landmark cases, such as Scheck in the US or the Pronuptia case in Europe, that have implications for the legal landscape and the regulation of the sector in these jurisdictions. ${ }^{31}$ It is also beyond the scope of this volume to survey business practices at the level of the market or contractual interaction. Obviously these aspects are also crucially important in assessing the regulatory regime in any given jurisdiction. The material presented here is, therefore, only one piece of a much larger picture.

Ideally, perhaps in the ten-volume revised version of this book, this assessment will encompass, inter alia, analysis of market usage and practice and contractual conventions in drafting and interpretation in each jurisdiction, with special attention to implied terms such as good faith. Such research would also examine various other factors influencing the regulatory environment such as the level of economic development; capitalist versus communist traditions; political and social factors; and cultural attitudes to business, themselves a product of religion, politics and economics.

It is also beyond the scope of this book to assess the effectiveness of regulation in achieving its ends in any given sector, or to determine whether regulation of the franchising sector in any given jurisdiction comports with

31 Scheck v. Burger King Corp. (756 F. Supp. 543 (S.D. Fla. 1991)) and Pronuptia Case, European Court of Justice, Case 161/84, 1986 CMLR 414. 
what is suggested as best regulatory practice, in terms of getting the best information, identifying the harms and selecting the best tools and strategies to address them; whether the process fully engages all the stakeholders; whether there is transparency and legitimacy. In practice every jurisdiction must engage in a process of gathering information about the conditions specific to it, to consult with stakeholders, to identify the specific risks and to address them.

What this book does aim to provide is a contextualized comparison of current practice in addressing the problems in franchising against the range of possible tools that are in theory available. The impetus for this survey of current regulatory regimes for the franchising sector globally grew out of research into the operation of the Australian franchise sector, where, after 30 years of experimentation with the regulation of the franchise sector, there is still no consensus about the effectiveness of the regulatory program for franchising. Four government inquiries into the regulation of the franchise sector in the past three years suggests that Australia has not yet achieved the best regulatory regime for its own particular requirements. There is even less reason to believe that it should be exported to other jurisdictions with their own particular circumstances, political, economic and social conditions and varying objectives. The question that this research sets out to answer is whether there is an ideal formulation for the regulation of the franchising sector, and if so, to identify the essential characteristics of that formulation.

For those who seek to understand them, the worlds of regulation and franchising may be both the stuff of myths. Perhaps the possibility of achieving a successful regulatory program tailored to the franchising sector is a myth in itself. But even if delivering balance and equity to franchising is a fairy tale, there are nevertheless lessons to be learned from fairy tales; and the quest for a grail, however futile, often brings out what is beautiful and worthwhile in the human spirit. 